Vol. 2 No. 2- August 2021

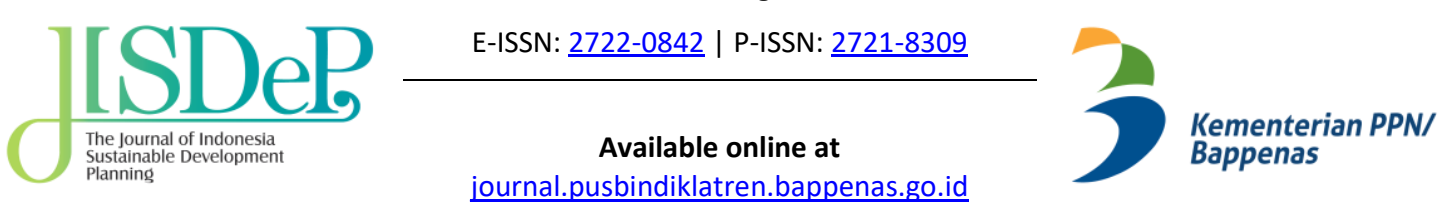

Research Paper

\title{
Infrastructure and Income Inequality in Indonesia: 2009-2017
}

\author{
Wiastuti Nurdina \\ Ministry of Agrarian and Spatial Affairs/National Land Agency, Indonesia \\ wiastuti.nurdina@gmail.com
}

\begin{abstract}
In the economic development field, physical and social infrastructure have been argued to affect income inequality despite the mixed results. This study examines the impact of physical and social infrastructure (education and health) on income inequality in Indonesia using 34 provincial unbalanced panel data during 2009-2017. Infrastructure summary indices are constructed, and the impacts of infrastructure on income inequality are estimated by the Generalized Method of Moments (GMM). The findings conclude that physical and social (education) infrastructure contributes to income inequality increases in Indonesia though not robustly significant. Regarding health infrastructure, this study cannot definitely infer its nexus with income inequality since only the model of one-step different-GMM is significant. The result implies that the government needs to consider providing better distribution of infrastructure among income groups to improve income distribution.
\end{abstract}

Keywords: physical infrastructure, social infrastructure, income inequality, GMM

\begin{tabular}{l|l|l}
\hline ARTICLE INFO & $\begin{array}{l}\text { JISDeP - The Journal of Indonesia } \\
\text { Sustainable Development Planning } \\
\text { Published by Centre for Planners' } \\
\text { Development, Education, and Training } \\
\text { (Pusbindiklatren), }\end{array}$ & $\begin{array}{l}\text { Address: Jalan Proklamasi 70, } \\
\text { Central Jakarta, Indonesia 10320 } \\
\text { Phone: }+622131928280 / 3192828 \\
\text { Fax: }+622131928281 \\
\text { E-mail: } \\
\text { Received }\end{array}$ \\
$\begin{array}{l}\text { Ministry of National Development } \\
\text { Accepted: August 23, 2021 }\end{array}$ & $\begin{array}{l}\text { Planning/ National Development } \\
\text { journal.pusbindiklatren@bappenas.go.id }\end{array}$ \\
& $\begin{array}{l}\text { Planning Agency (Bappenas), Republic } \\
\text { of Indonesia }\end{array}$ & $\begin{array}{l}\text { Supported by Indonesian Development Planners } \\
\text { Association (PPPI) }\end{array}$ \\
C 2021 The Author & & \\
\hline
\end{tabular}




\section{Introduction}

As a growing country, Indonesia experiences sustained economic growth during the past few years. Nevertheless, the benefits of economic growth have not yet been equally distributed across income groups. The level of income inequality measured by the Gini ratio in Indonesia was reported to nearly remain the same during 1975-2004, but increased to 41 points in 2014, and was the highest compared to its East Asian neighbors (e.g., Japan and China) (Hill et al., 2008; World Bank, 2016). A lack of access to infrastructure-leading to unequal education, health, and job opportunities - is claimed to be a major cause of large income gaps in Indonesia (Doumbia \& Kinda, 2019; World Bank, 2016). The World Bank (2016) argues that reducing income inequality is important since it can hinder economic growth, foster poverty rates, and trigger social conflicts. Having the concern to reduce income inequality in Indonesia, the government has been increasing infrastructure development to improve opportunities distribution (e.g., education, health, and jobs). As a result, the government has been increasing its budget to improve physical and social infrastructure access for years, especially in lagging regions.

Theoretically and empirically, infrastructure is believed to be able to narrow income gaps (Calderón \& Servén, 2004; Chong \& Calderón, 2004; Kannan et al., 2018). Nevertheless, some empirical studies find that infrastructure may increase income inequality due to unequal distribution of returns (Bajar \& Rajeev, 2016; Majumder, 2012). In accordance with these empirical results, Makmuri (2017) also finds that physical infrastructure like transportation, telecommunications, and electricity contribute to income inequality increases in Indonesia. The different impacts of infrastructure on income inequality in each country can be explained by the influence of the initial level of income inequality, stage of development, and level of infrastructure development (Tian \& Li, 2019). Considering the previous mixed results and the Indonesian efforts to reduce income inequality by improving infrastructure development, the research question is whether infrastructure development can reduce income inequality in Indonesia.

Accordingly, this study aims to investigate the impact of physical and social infrastructure development on income inequality in Indonesia since the issue has not been commonly examined in Indonesia. This study contributes to the literature in Indonesia by investigating the impact of both social infrastructure (education and health) and physical infrastructure on income inequality. The relationship between social infrastructure and income inequality has not been generally explored in Indonesia since some studies only focus on physical infrastructure (Kannan et al., 2018; Makmuri, 2017). This study extends the Calderón \& Servén (2004) model that focuses on physical infrastructure (e.g., transportation, telecommunications, electricity) on income inequality by adding social infrastructure (i.e., education and health). Social infrastructure is argued to be associated with human capital accumulation, which affects economic growth and improves income distribution (De \& Halder, 2016; More \& Aye, 2017). This study follows Calderón \& Servén (2004) by creating a summary index of infrastructure quantity and estimating its impact using the Generalized Method of Moments (GMM). The analysis in this study is based on 34 provincial panel data in Indonesia between 2009 and 2017. In accordance with Makmuri (2017), the estimation results show that physical infrastructure development in Indonesia tends to increase income inequality. Similarly, the development of social infrastructure in Indonesia also leads to higher income inequality.

Physical infrastructure that refers to several kinds of infrastructure such as transportation, telecommunications, and electricity, directly affects economic growth (Torrisi, 2009). Generally, physical infrastructure is found to be able to indirectly affect income gaps through physical capital accumulation and economic growth (Calderón et al., 2014; Calderón \& Servén, 2004; Jones \& Llewellyn, 2019; Kannan et al., 2018). For instance, roads have been argued to be necessary for narrowing income inequality by enlarging markets, increasing productivity, promoting working opportunities, improving access to education and health services, and improving living (Charlery et al., 2016; Hooper et al., 2018; World Bank, 2016). Similarly, telecommunications and electricity have also been observed to improve income distribution through economic growth like information and technology sharing, production, and labor markets (Cook, 2011; Röller \& Waverman, 2001). Numerous previous studies find contradicting results regarding the infrastructure-income inequality relationship. Calderón and Servén (2004) conclude that physical infrastructure in the long-term accelerates economic growth and has a significant inverse relationship with income inequality. Meanwhile, physical infrastructure is found to have a positive impact on income inequality increases in India (Bajar \& Rajeev, 2016; Majumder, 2012) and Indonesia (Makmuri, 2017). It is argued that the positive physical infrastructure-income inequality is possibly due to unequal returns of physical infrastructure between the rich and the poor (Bajar \& Rajeev, 2016; Makmuri, 2017). Compared to the poor, the rich might profit much more from physical infrastructure (Cook, 2011; United 
Nations, 2016). Moreover, physical infrastructure development is argued to increase income gaps since it fosters "technological changes, globalization, and market-oriented reform" which may favor high-skilled laborers (Zhuang et al., 2014).

In addition to physical infrastructure, access to social infrastructure is also argued to be able to narrow income inequality distribution, indirectly through promoting better opportunities to have better education, health status, and participation in high-skilled labor markets (Hooper et al., 2018; United Nations, 2016). Social infrastructure (e.g., education and health) is reported to indirectly affects economic growth through promoting opportunities in improving human capital (Torrisi, 2009). Promoting opportunities for the poor to graduate from higher education is required for higher growth and lowerincome inequality since it creates high-skilled laborers (De \& Halder, 2016; Hasanov \& Izraeli, 2011). Income inequality increases in Mexico are attributed to the different returns to education since the return to higher education is higher than primary education (Bouillon et al., 2003). Besides education, health infrastructure (e.g., hospitals, doctors) also matters in improving endowments, promoting opportunities in gaining higher income, and eventually reducing income inequality (Majumder, 2012; More \& Aye, 2017). Majumder (2012) highlights the significant impact of providing better health services on improving income distribution and education services in India. In addition to health services (e.g., hospitals and doctors), some researchers consider water and sanitation to affect health and indirectly improve income distribution (Biller et al., 2014; Calderón \& Servén, 2004; Straub \& Fay, 2017). They argue that water and sanitation are associated with health externalities and indirectly impact welfare and quality of life. Improving sanitation and water efficiency is suggested to improve health conditions and reduce health expenditures; hence, disposable income and income distribution could improve (Mendoza, 2017).

This paper is divided into five sections. This section gives a brief overview of the background, the objective of the study, and the literature review. The second section explains the development of physical infrastructure and social infrastructure development in each province in Indonesia. The third section explains the empirical analysis, which contains the data and empirical strategies. In the fourth section, the empirical results of this study and discussions are presented. Lastly, conclusions are drawn in section five.

\section{Provincial Physical Infrastructure and Social Infrastructure Development in Indonesia}

In addition to estimating the impact of infrastructure on income inequality, it is important to picture the level of infrastructure development of each province in Indonesia. Therefore, it can generally show the gap in infrastructure development between provinces in Indonesia. The average value of physical infrastructure development level from 2009 to 2017 in each province can be seen in Figure 1, while the average value of social infrastructure development is shown in Figure 2. The average value of physical and social development is represented by the infrastructure summary indices constructed using methods as informed in the methodology section.

Figure 1 informs that generally, there is quite a significant gap in the physical infrastructure development level between provinces in Indonesia. In particular, DKI Jakarta province, where the capital city of Indonesia is located, has the highest index of physical infrastructure development (about 7.0) compared to other provinces. Moreover, the level of physical infrastructure development in some provinces in Java which are considered as developed regions is also generally above the other provinces in other islands. Conversely, the level of physical infrastructure development in less developed regions located in Eastern Indonesia (e.g., Maluku, Papua) is in general below zero and the smallest (-1.7) compared to other provinces. It probably reflects that the development of physical infrastructure in Indonesia has not been equally distributed. Moreover, it also shows that provinces with higher economic development and more policy support, mainly concentrated in Western Indonesia, tend to have a higher level of physical infrastructure development. Accordingly, it may explain that the different level of physical infrastructure in Indonesia is affected by economic development and policy support. In addition, it depicts the possible reverse causality between physical infrastructure development and economic development.

Figure 2 shows the distribution of the average value of the social infrastructure development index between 2009 and 2017 in Indonesia. Different from physical infrastructure, the gap level of social infrastructure development between provinces in Indonesia is not as large as the distribution of physical infrastructure. For example, other provinces such as Bali, Jawa Barat, Jawa Tengah, Jawa Timur, and D.I. Yogyakarta also have a quite similar level of social infrastructure to DKI Jakarta. In general, provinces in Java and Bali have a considerable high level of social infrastructure development (about 1 to 2.6 points). 
Meanwhile, the average value of social infrastructure development in other regions (i.e., Sumatera, Sulawesi, Maluku, Papua) is generally lower than zero (about -0.5 to -1.5 ). Considering the social infrastructure development level, it seems that the government focused more on improving human capital development directly. Nevertheless, some provinces have a low average value of social infrastructure development, such as Bengkulu, Papua, Nusa Tenggara Barat, and Nusa Tenggara Timur. Previously, an infrastructure census conducted by World Bank in 2011 reports that some subdistricts in Papua have no health services (e.g., Puskesmas, public health center). Moreover, Mahendradhata et al., (2017) and World Health Organization (2017) find that safe water, sanitation, and health services such as Puskesmas are barely found in remote areas or remote islands in Indonesia.

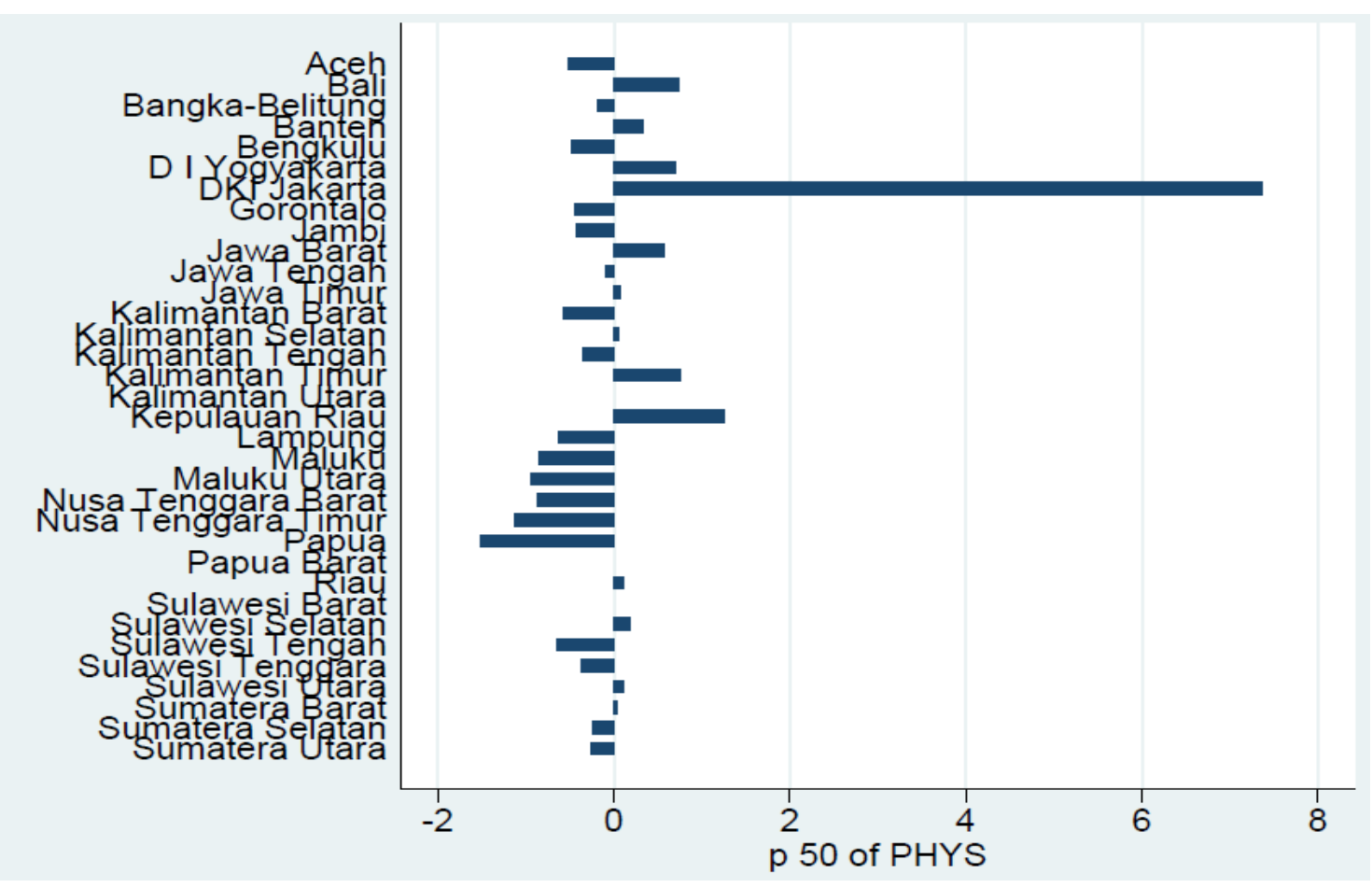

Figure 1. Average Value of Physical Infrastructure Index, 2009-2017 (Author's calculation, 2020)

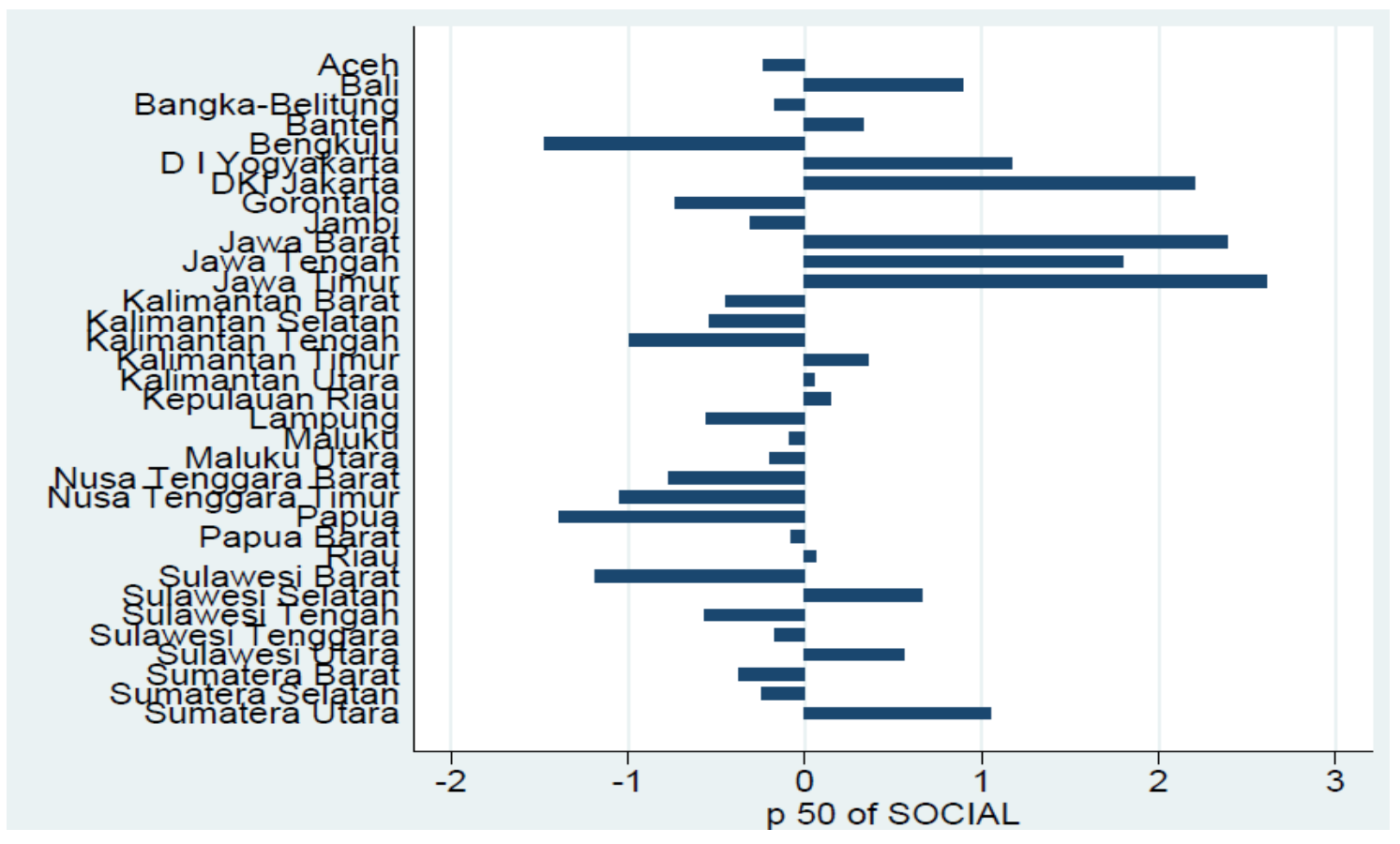

Figure 2. Average Value of Social Infrastructure Index, 2009-2017 (Author's calculation, 2020) 


\section{Methodology}

\subsection{Data}

This study uses 34 provincial panel data in Indonesia from 2009 to 2017 . Due to some missing data before 2009 (combined Gini ratio, electricity, telecommunications, education, health, safe water, sanitation, and some control variables), this study decides to use data from 2009 onward to minimize the missing data. Moreover, there are also missing data for the years after 2017, such as doctor ratio and hospital ratio taken from Indonesia Health Profile published by the Ministry of Health Republic of Indonesia. A similar case also applies to data of income inequality and some control variables, for instance, financial development and the modern sector. Accordingly, in order to minimize missing data, the author decides to use a certain period. The descriptive statistics of each variable are informed in Table 1.

Table 1: Descriptive Statistics

\begin{tabular}{|c|c|c|c|c|c|}
\hline Variables & Obs. & Mean & SD & Min & Max \\
\hline Gini ratio & 300 & 0.366 & 0.040 & 0.27 & 0.46 \\
\hline Physical Infrastructure & 279 & $-2.84 \mathrm{e}-10$ & 1.500 & -1.811 & 7.850 \\
\hline Education Infrastructure & 301 & $-3.86 e-09$ & 1.397 & -1.134 & 5.186 \\
\hline Health Infrastructure & 300 & $-1.58 \mathrm{e}-09$ & 1.472 & -3.067 & 4.580 \\
\hline Income per capita (In) & 301 & 10.267 & 0.573 & 9.108 & 11.968 \\
\hline Income per capita sq (In) & 301 & 105.744 & 12.110 & 82.953 & 143.241 \\
\hline Financial development & 297 & 0.277 & 0.352 & 0.020 & 2.330 \\
\hline Trade openness & 297 & 35.515 & 34.450 & 0.150 & 194.770 \\
\hline Modern sector & 297 & 0.126 & 0.097 & 0.000 & 0.450 \\
\hline Government spending & 301 & 0.355 & 0.023 & 0.010 & 0.120 \\
\hline
\end{tabular}

Sources: Author's calculation

\subsubsection{Income Inequality}

In order to employ a regression analysis, this study uses the data of income inequality as the dependent variable. The income inequality is represented by the combined Gini ratio (urban and rural), which is obtained from the Statistics Indonesia (BPS) and calculated based on the National Socioeconomic Survey (SUSENAS) every year.

\subsubsection{Infrastructure Variables}

Infrastructure variables as the main independent variables are measured by infrastructure summary indices consisting of physical and social infrastructure. Physical infrastructure contains transportation, telecommunication, and electricity which were mainly used by previous similar studies such as Calderón \& Servén (2004), Majumder (2012), Li et al., (2015), Bajar \& Rajeev (2016), and Makmuri (2017). Meanwhile, social infrastructure variables used data of education, health services, safe water, and sanitation which were utilized by previous studies such as Majumder (2012), Li et al., (2015), and More \& Aye (2017). The data of infrastructure variables were mainly obtained from Statistics Indonesia (BPS). This study focuses only on the quantity of infrastructure for two reasons: first, the availability of provincial infrastructure quality data in Indonesia is void; second, infrastructure stocks in developing countries are argued to be more influential on income inequality than infrastructure quality (Chong \& Calderón, 2004).

First, transportation data were taken from Statistics Indonesia (BPS) and published in Statistical Yearbook of Indonesia. Transportation quantity is represented by the ratio of road length and the land area $\left(\mathrm{km} / \mathrm{km}^{2}\right)$. The road is generally believed to help enlarge the market, increase production, improve access to social infrastructure, which are essential for improving income distribution. In addition to the road, this study adds the number of buses per 10,000 people to represent the access provided by the 
government for public transportation. Considering the characteristics of Indonesia as an archipelago country, sea and air transportation or railways are also as necessary as road and bus. However, due to limited data of provincial railways, seaports, or airports quantity data, the author decideed to use road and bus as indicators. The author realized that focusing on land transportation limits this study.

Second, telecommunications in this study are indicated by mobile phone (percentage of households with at least one mobile phone), internet (percentage of households who access the internet at least once at the last three months), and computer (percentage of households with a computer). The data were taken from Telecommunications Statistics of Indonesia published by Statistics Indonesia (BPS). Unlike previous studies that used data of conventional telecommunications such as fixed telephone, this study applies modern telecommunications associated with economic activities in this digital era. As widely argued, telecommunications are necessary to indirectly improve income distribution by generating economic growth due to their role in information sharing.

Third, this study indicates electricity using electricity distributed per capita (MWh/capita). The data on electricity were obtained from Statistical Yearbook of Indonesia, which was published annually by Statistics Indonesia (BPS). Electricity is necessary for the production process and information or technology sharing because it can generate economic growth and indirectly affects income distribution. Furthermore, electricity also gives more time to study and access modern telecommunication such as mobile phones, computers, and the internet that helps productivity and information sharing to promote opportunities in jobs and earning a higher income.

Fourth, education variables are constructed from primary education and higher education. Primary education is measured by the number of primary schools per 1,000 people and the number of junior high schools per 1,000 people. Higher education is indicated by the number of high schools per 1,000 people, vocational high schools per 1,000 people, and colleges per 1,000 people. The data were taken from Statistical Yearbook of Indonesia annually published by Statistics Indonesia (BPS). Yang \& Qiu (2016) argued that primary education shows an important role in income inequality and intergeneration income mobility. Furthermore, higher education also plays an important role in income distribution since it creates high-skilled labor, as suggested by Hasanov \& Israeli (2016) and De \& Halder (2016).

Fifth, health variables are indicated by doctor ratio (number of doctors per capita times 1,000) and hospital ratio (number of doctors per capita times 1,000). The data were obtained from Indonesia Health Profile annually published by the Ministry of Health Republic of Indonesia. Health services such as doctors and hospitals improve endowments and promote opportunities to earn a higher income.

Six, the water variable is measured by the percentage of households with improved drinking water. The data were obtained from Statistical Yearbook of Indonesia annually published by Statistics Indonesia (BPS). Safe water is important to improve health and quality of life. Straub and Fay (2017) argue that water is associated with health externalities and indirectly affects welfare and quality of life. Hence, people with good health conditions are more likely to have more working hours and better opportunities to gain higher income.

Seven, sanitation variable is proxied by percentage of households with improved access to sanitation. The data was taken from Statistical Yearbook of Indonesia annually published by Statistics Indonesia (BPS). Similar to water, sanitation also plays a role in income distribution by improving health and quality of life. Straub and Fay (2017) also state that sanitation has an association with health externalities and may improve quality of life. Furthermore, good health conditions are achieved because good access to improved sanitation may reduce household health expenditure and indirectly generate better disposable income.

\subsubsection{Control Variables}

According to previous similar studies, Calderón and Servén (2004), Li et al., (2017), and Makmuri (2017), five control variables were included in the regression analysis. First, the income variable and its square, proxied by per capita Gross Regional Domestic Product (GRDP) in logarithm and its squared, to estimate a non-linear relationship between growth and inequality, depicted by Kuznet curve. The data were obtained from Statistical Yearbook of Indonesia published by Statistics Indonesia (BPS). If the nonlinear relationship holds true, the coefficient of per capita income (log) should be positive, and the coefficient for its square should be negative, as previously shown by Calderón and Servén (2004). In other words, it implies that the level of income inequality increases in the beginning process of development and starts declining after reaching its peak level. 
Second, financial development is argued to indirectly impact income inequality through economic growth (Zhang \& Ben Naceur, 2019). Zhang and Ben Naceur (2019) argue that providing access to credits for the poor is believed to minimize financial constraints and induce them to invest in incomegenerating activities and human capital. Conversely, in Bangladesh, financial development can be harmful to the poor due to the increased debt level (Banerjee \& Jackson, 2017). Considering these arguments, the sign of the influence of financial development on income inequality could be positive or negative. The proxy of this variable is the share of total private credits to GRDP and obtained from Financial Services Authority of Indonesia.

Third, trade openness indirectly influences income inequality through economic development and employment (Kai \& Hamori, 2009). Some studies find the contribution of trade openness to be positive, but others find it to be negative. Kai and Hamori (2009) state that recent export-import industries require more high-skilled labor than low-skilled labor since they are related to high technology. Nevertheless, if there is a large labor skill gap, the intensive trade openness may risk income distribution. Therefore, the predicted sign of the trade openness variable cannot be clearly predicted. Trade openness is proxied by the ratio of total export and import to GRDP and obtained from Gross Regional Domestic Product of Province in Indonesia by Expenditure published by Statistics Indonesia (BPS).

Furthermore, the modern sector is also argued to influence income inequality (World Bank, 2016). It is explained that rising more productive and semi-skilled jobs may result in vast inequality due to rising wage gaps between high-skilled and low-skilled laborers. Moreover, The World Bank (2016) states that high-skilled worker's productivity in industrial sectors contributes $1 \%$ of higher real wage growth. Nevertheless, Zhuang et al., (2014) argue that it may increase income inequality if there is a large gap in labor skills since it mostly favors high-skilled laborers. Accordingly, this study includes the share of total value added of the industry to GRDP obtained from Gross Regional Domestic Product of Province in Indonesia by Expenditure published by Statistics Indonesia (BPS).

Fifth, this study includes the share of government spending to GRDP obtained from Statistical Yearbook of Indonesia published by Statistics Indonesia (BPS). Li et al., (2017) include this variable to examine the impact of local government intervention on economic development that also affects income inequality. The relationship between government spending and income inequality is ambiguous. It is found to be negative (Li et al., 2017), while it is also found to be positive (Bajar \& Rajeev, 2016). The sign of the government spending variable cannot be predicted yet.

\subsection{Constructing the Infrastructure Summary Indices}

There are two different approaches in measuring infrastructure: monetary and physical (Torrisi, 2009). Commonly, the monetary approach uses the amount of money invested in developing infrastructure like government expenditure in infrastructures, whereas the physical approach uses the quantity of infrastructure, for instance, length of roads and number of schools or hospitals. In measuring infrastructures, this study uses a physical approach instead of a monetary approach. Torrisi (2009) argues that a monetary approach is less efficient because of corruption or inefficient investment and is only able to capture infrastructure developed by the public sector. Meanwhile, the physical approach is preferred since it can represent infrastructure development provided by both public and private sectors. Hence, this study uses the physical approach to measure infrastructure development.

Generally, empirical studies rely on specific indicators (e.g., transportation, telecommunications, electricity) to proxy infrastructures, such as Charlery et al., (2016) and Bajar and Rajeev (2016). Conversely, Calderón et al., (2014) argue that specific indicators are not sufficient to thoroughly depict the impact of physical infrastructures on income inequality and may result in misleading information. Consequently, constructing an infrastructure summary index from the combination of specific indicators (e.g., transportation, telecommunications, electricity) is reasonable to comprehensively portray infrastructure and estimate its impact on income inequality. Other subsequent studies (Chong \& Calderón, 2004; Majumder, 2012; Makmuri, 2017; Raychaudhuri \& De, 2010; Seneviratne \& Sun, 2013) apply the same method to examine the relationship between infrastructure and income inequality.

Accordingly, this study applies the methods proposed by Calderón and Servén (2004), who constructed infrastructure indices using Principal Component Analysis (PCA), and followed by Makmuri (2017), who conducted a similar study in Indonesia. This study expands the methods by: estimating the impact of social infrastructure (education infrastructure/EDUC and health infrastructure/HEALTH) and 
physical infrastructure (PHYS), employing more infrastructure indicators, applying annual within-country data to obtain less information loss, and using the advanced telecommunications indicators (mobile phone, internet, computers) instead of fixed telephone. In this study, physical infrastructure (PHYS) and social infrastructure (EDUC, HEALTH) are combined from several previously constructed components from some related indicators. Since education and health are weakly correlated, and PCA requires high correlation among variables to summarize the variation of the large interrelated variables, grouping education and health into one summary index seems unsuitable. Therefore, social infrastructure will be categorized into two variables called education (EDUC) and health (HEALTH). Education infrastructure (EDUC) consists of primary education (combined from primary school and junior high school) and higher education (combined from high school, vocational high school, and college). Public health services (e.g., doctors and hospitals), water, and sanitation are combined to construct a summary infrastructure index called HEALTH.

As for the physical infrastructure index, the first principal component of the three indicators (transportation, telecommunications, electricity) accounts for $74.59 \%$. The physical infrastructure index (PHYS) is strongly correlated with transportation (0.89), telecommunications (0.71), and electricity (0.97). The physical infrastructure synthetic index can be expressed as:

$$
\text { PHYS }_{i t}=0.5965 T R A N S P O R T_{i t}+0.4765 T E L C O M_{i t}+0.6458 E L E C_{i t}
$$

where $i$ is province, $t$ is years, $P H Y S_{i t}$ is the physical infrastructure index, TRANSPORT $i t$ is the transportation infrastructure index (road and bus), TELCOM $M_{i t}$ is the telecommunications infrastructure index (mobile phone, internet, computer), $E L E C_{i t}$ is per capita distributed electricity to represent electricity.

As for the education infrastructure index, the first principal component of the two indicators, primary education (PEDUC) and higher education (HEDUC), account for $97.59 \%$. The education infrastructure index (EDUC) is strongly correlated with primary education (0.99) and higher education (0.99). The education infrastructure synthetic index can be expressed as:

$$
E D U C_{i t}=0.7071 P E D U C_{i t}+0.7071 H E D U C_{i t}
$$

where $i$ is province, $t$ is years, $E D U C_{i t}$ is the education infrastructure index, $P E D U C_{i t}$ is the primary education infrastructure index (primary school and junior high school), and $H E D U C_{i t}$ is the higher education infrastructure index (high school, vocational high school, and college).

As for the health infrastructure index, the first principal component of the three indicators (PHEALTH - doctor and hospital, safe water, improved sanitation) accounts for $72.25 \%$. The health infrastructure index (HEALTH) is strongly correlated with PHEALTH (0.77), safe water (0.87), and improved sanitation (0.90). The health infrastructure synthetic index can be expressed as:

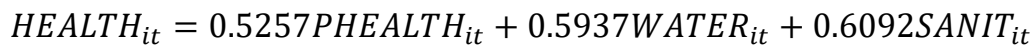

where $\mathrm{i}$ is province, $\mathrm{t}$ is years, $H E A L T H_{i t}$ is the health infrastructure index, PHEALTH $H_{i t}$ is the public health infrastructure index (doctor and hospital), WATER $R_{i t}$ is percentage of households with access to safe water, $S A N I T_{i t}$ is percentage of households with access to improved sanitation.

\subsection{Econometric Model}

This study estimates the impact of infrastructure on income inequality by applying a dynamic panel data regression model that includes the lagged dependent variable as a regressor. It follows previous similar studies such as Calderón and Servén (2004), Chong and Calderón (2004), Majumder (2012), Hasanov and Izreali (2011), and Raychaudhuri and De (2010). They argue that it is reasonable to apply GMM to overcome the potential endogeneity problem that is commonly found in infrastructureinequality nexus. There is a possible two-way correlation between infrastructure and inequality or other observed and unobserved heterogeneity such as urbanization, government size, industrialization, and others. Moreover, different initial levels of inequality across regions may also influence the impact of infrastructure on inequality (United Nations, 2016). Therefore, conducting a dynamic panel data analysis is required by including a lag of the dependent variable as a regressor. 
The general model to investigate the impact of infrastructure on income inequality is described as follows:

$$
\begin{aligned}
& \operatorname{Gini}_{i t}=\alpha \operatorname{Gini}_{i t-1}+X_{i t}^{\prime} \beta+Z_{i t}^{\prime} \gamma+u_{i t} \\
& u_{i t}=\mu_{i}+\varepsilon_{i t}
\end{aligned}
$$

where $i$ is province, $t$ is years, Gini $_{i t}$ is income inequality level measured by the Gini ratio, $\operatorname{Gini}_{i(t-1)}$ is the lag phase of the dependent variable (Gini ratio), $X_{i t}$ is a set of infrastructure-related measures (PHYS, EDUC, HEALTH), $Z_{i t}$ is a set of control variables (log of income, log of income squared, financial development, trade openness, government spending, and modern sector), $\mu_{i}$ is individual effect, and $u_{i t}$ is the stochastic disturbance term. This model implicitly includes a constant term.

In order to estimate the parameters, this study employs GMM (Generalized Method of Moments), which is common and broadly used in empirical studies. With the purpose of controlling the fixed effect $\left(\mu_{i}\right)$, Equation (4) needs to be modified by taking the first differences so that the fixed effect is eliminated. The first difference regression is expressed as:

$$
\Delta \operatorname{Gini}_{i t}=\alpha \Delta \operatorname{Gini}_{i t-1}+\Delta X^{\prime}{ }_{i t} \beta+\Delta Z_{i t}^{\prime} \gamma+\Delta u_{i t}
$$

Based on Equation (5), Difference GMM (Diff-GMM) estimates the parameters by using the lagged level of regressors as instruments. Specifically, the Diff-GMM uses the following moment conditions:

$$
\begin{aligned}
& E\left(Y_{i, t-s} \cdot \Delta u_{i t}\right)=0, \text { for } s \geq 2 ; t=3, \ldots, T \\
& E\left(\omega_{i, t-s} \cdot \Delta u_{i t}\right)=0, \text { for } s \geq 1 ; t=3, \ldots, T
\end{aligned}
$$

where $Y$ is income inequality (Gini ratio), $\omega$ is a set of the other regressors (i.e., infrastructure variables and control variables) of the level Equation (4), $\mu_{i}$ is the individual effect, and $u_{i t}$ is the disturbance term.

This study assumes that all regressors are predetermined, influenced by previous periods but not in the future, to support the employment of GMM. Therefore, all variables are instrumented by the first lag, which follows the moment conditions explained above. Due to the long period taken, it leads to instruments proliferation when using GMM estimators. Since instruments proliferation may cause failure in overcoming endogeneity and biased estimates, reducing the number of instruments is necessary (Roodman, 2009). To prevent instruments proliferation, this study reduces the number of instruments by two methods. First, collapsing the instruments as explained in Roodman (2009); second, using only the first two acceptable once-lagged levels of the regressors in Diff-GMM and as for System-GMM, using only the first acceptable once-lagged level of the regressors for Equation (5) and the lag zero of the instrument variables in differences for Equation (4) as the instruments.

In applying GMM, ensuring the validity of instruments and serially uncorrelated error terms are crucial. Hence, following Roodman (2009), two standard specification tests are required to support the use of GMM; first, over-identifying tests (Sargan and Hansen tests) that test whether the instruments are exogenous; and second, a specification test that examines the serial correlation of the error term. In order to provide valid instruments, the instruments used should not be correlated with the new error terms. Neither test is supposed to reject the null hypothesis to support the GMM model.

\section{Results and Discussions}

This section discusses the contribution of physical and social infrastructure to income inequality based on the estimation results. It will first discuss the distribution level of infrastructure development across provinces to depict the regional gap level of infrastructure development in Indonesia. Then, this study will discuss the contribution of physical and social infrastructure (education and health) to income inequality in Indonesia. Following previous studies such as Calderón and Servén (2004), this study employs several variants of Diff-GMM and System-GMM with one-step and two-step estimations to conclude the estimation results more comprehensively. 


\subsection{Physical Infrastructure, Social Infrastructure, and Income Inequality}

The estimation results of the impact of physical and social (education and health) infrastructure quantity indices on income inequality in Indonesia are represented in Table 2 using different techniques. The results in Column [1] and [2] inform the estimation results of pooled OLS and time-effects models, respectively. Moreover, Column [3] and [4] report the results of one-step and two-step Diff-GMM, respectively. Column [5] and [6] report the estimates of one-step and two-step System-GMM, respectively. The discussion of this study will focus on the estimation results of the GMM estimators. Table 2 reports that none of the control variables is found to significantly affect income inequality in Indonesia.

Generally, except for the one-step System-GMM model in Column [5], the models applied and the estimation results in Table 2 satisfy the specification tests. Instrument variables in all models in Table 2 are serially uncorrelated with the error terms, which are showed by the AR test's coefficient (using a 5\% significance level). Meanwhile, only the model in Column [5] violates the requirements regarding the overidentifying test (Sargan/Hansen test) due to its instrument variables' correlation with the error (using 5\% significance level). Consequently, the estimates of Column [5], one-step System-GMM, is counted out from analysis, and analysis is based on the results of Column [3], [4], and [6].

Considering the estimation results, generally, physical and social infrastructure development is more likely to increase income inequality in Indonesia. It is inferred by the positive signs of physical infrastructure, education infrastructure, and health infrastructure. Considering all estimation results, the signs of physical infrastructure and education infrastructure are quite consistent, which is positive. The consistency also appears for the statistical significance of the estimation results, particularly for education infrastructure. Meanwhile, the estimates of health infrastructure do not show a consistent sign and significance across estimates. It can be inferred that education infrastructure may have a stronger significant impact on income inequality increases in Indonesia, followed by physical infrastructure. Conversely, health infrastructure probably has the least impact on income distribution in Indonesia.

Table 2: Physical Infrastructure, Social Infrastructure, and Income Inequality

Dependent variable: Gini ratio

\begin{tabular}{|c|c|c|c|c|c|c|}
\hline Variables & $\begin{array}{c}\text { (1) } \\
\text { Pooled OLS }\end{array}$ & $\begin{array}{c}(2) \\
\text { Time-Effects }\end{array}$ & $\begin{array}{c}\text { (3) } \\
\text { one-diff }\end{array}$ & $\begin{array}{c}\text { (4) } \\
\text { two-diff }\end{array}$ & $\begin{array}{c}\text { (5) } \\
\text { one-sys }\end{array}$ & $\begin{array}{c}\text { (6) } \\
\text { two-sys }\end{array}$ \\
\hline L.gini & & & $\begin{array}{c}0.5006^{* * *} \\
(0.1393) \\
\end{array}$ & $\begin{array}{c}0.5345^{* *} \\
(0.2458) \\
\end{array}$ & $\begin{array}{c}0.4525^{* * *} \\
(0.1078) \\
\end{array}$ & $\begin{array}{c}0.3994 * * \\
(0.1361)\end{array}$ \\
\hline Physical Infrastructure & $\begin{array}{l}0.0039 * \\
(0.0021)\end{array}$ & $\begin{array}{c}0.0092 \\
(0.0073)\end{array}$ & $\begin{array}{l}0.0656^{* *} \\
(0.0330)\end{array}$ & $\begin{array}{c}0.0756^{* * *} \\
(0.0242) \\
\end{array}$ & $\begin{array}{c}0.0102 \\
(0.0084)\end{array}$ & $\begin{array}{c}0.0101 \\
(0.0129)\end{array}$ \\
\hline $\begin{array}{l}\text { Education } \\
\text { Infrastructure }\end{array}$ & $\begin{array}{c}0.0078^{* * *} \\
(0.0026)\end{array}$ & $\begin{array}{l}0.0174^{*} \\
(0.0094)\end{array}$ & $\begin{array}{c}0.0685^{* *} \\
(0.0290)\end{array}$ & $\begin{array}{c}0.0812 * * \\
(0.0348)\end{array}$ & $\begin{array}{c}0.0058 \\
(0.0056)\end{array}$ & $\begin{array}{c}0.0131 \\
(0.0089)\end{array}$ \\
\hline Health Infrastructure & $\begin{array}{l}-0.0010 \\
(0.0022)\end{array}$ & $\begin{array}{c}0.0036 \\
(0.0030)\end{array}$ & $\begin{array}{l}0.0221^{*} \\
(0.0120)\end{array}$ & $\begin{array}{c}0.0188 \\
(0.0135)\end{array}$ & $\begin{array}{c}0.0067 \\
(0.0057)\end{array}$ & $\begin{array}{c}0.0106 \\
(0.0077)\end{array}$ \\
\hline Income/capita (In) & $\begin{array}{c}0.0915 \\
(0.0891)\end{array}$ & $\begin{array}{l}-0.3925 \\
(0.2419)\end{array}$ & $\begin{array}{l}-0.6772 \\
(0.5965)\end{array}$ & $\begin{array}{l}-0.9505 \\
(0.6204)\end{array}$ & $\begin{array}{l}-0.2453 \\
(0.2810)\end{array}$ & $\begin{array}{c}0.1180 \\
(0.5638)\end{array}$ \\
\hline Income/capita.sq (In) & $\begin{array}{l}-0.0043 \\
(0.0042)\end{array}$ & $\begin{array}{l}0.0230 * \\
(0.0118)\end{array}$ & $\begin{array}{c}0.0308 \\
(0.0263)\end{array}$ & $\begin{array}{c}0.0418 \\
(0.0270)\end{array}$ & $\begin{array}{l}-0.0095 \\
(0.0127)\end{array}$ & $\begin{array}{l}-0.0071 \\
(0.0265)\end{array}$ \\
\hline Financial development & $\begin{array}{c}0.0317 * * * \\
(0.0050)\end{array}$ & $\begin{array}{c}0.0280 \\
(0.0220)\end{array}$ & $\begin{array}{l}-0.0276 \\
(0.0485)\end{array}$ & $\begin{array}{l}-0.0552 \\
(0.0471)\end{array}$ & $\begin{array}{l}-0.0048 \\
(0.0102)\end{array}$ & $\begin{array}{c}0.0040 \\
(0.0235)\end{array}$ \\
\hline Trade openness & $\begin{array}{c}0.0000 \\
(0.0001)\end{array}$ & $\begin{array}{l}-0.0001 \\
(0.0002)\end{array}$ & $\begin{array}{c}0.0001 \\
(0.0005)\end{array}$ & $\begin{array}{c}0.0000 \\
(0.0004)\end{array}$ & $\begin{array}{c}0.0004 \\
(0.0003)\end{array}$ & $\begin{array}{c}0.0003 \\
(0.0004)\end{array}$ \\
\hline Modern sector & $\begin{array}{c}-0.1346 * * * * \\
(0.0454)\end{array}$ & $\begin{array}{c}-0.1229 * * \\
(0.0527) \\
\end{array}$ & $\begin{array}{c}0.3865 \\
(0.2619)\end{array}$ & $\begin{array}{c}0.3904 \\
(0.2892)\end{array}$ & $\begin{array}{l}-0.1277 \\
(0.1005)\end{array}$ & $\begin{array}{l}-0.2593 \\
(0.1746)\end{array}$ \\
\hline Government spending & $\begin{array}{c}-0.2623^{*} \\
(0.1370) \\
\end{array}$ & $\begin{array}{l}-0.1577 \\
(0.2450)\end{array}$ & $\begin{array}{c}0.0173 \\
(0.9053)\end{array}$ & $\begin{array}{c}0.3929 \\
(0.9788)\end{array}$ & $\begin{array}{l}-0.1413 \\
(0.2836)\end{array}$ & $\begin{array}{l}-0.1676 \\
(0.8460)\end{array}$ \\
\hline $\begin{array}{l}\mathrm{N} \text { (number of } \\
\text { observations) }\end{array}$ & 279 & 279 & 217 & 217 & 248 & 248 \\
\hline $\begin{array}{l}\text { J (number of } \\
\text { instruments) }\end{array}$ & & & 27 & 27 & 28 & 28 \\
\hline$A R(1) p$ & & & 0.000 & 0.004 & 0.000 & 0.001 \\
\hline $\operatorname{AR}(2) p$ & & & 0.558 & 0.528 & 0.143 & 0.201 \\
\hline Sargan/Hansen $p$ & & & 0.305 & 0.248 & 0.050 & 0.192 \\
\hline
\end{tabular}

Standard errors in parentheses * $p<0.10, * * p<0.05, * * * p<0.01$

Sources: Author's calculation 
Regarding the magnitude, the coefficients in Column [3] and [4] show that the development of physical and education infrastructure has a significantly higher impact on income inequality increases in Indonesia compared to health infrastructure. An increase in physical infrastructure development has increased income inequality by around 0.066 to 0.076 points at $1-5 \%$ significant level, ceteris paribus. However, Columns [5] and [6] report that the impact of physical infrastructure on income inequality loses its significance when system-GMM is applied to estimate the parameter. As for education infrastructure, the level of income inequality in Indonesia increased by around 0.069 to 0.081 points when education infrastructure development increased by one point at $5 \%$ significant level, other factors being constant. In general, physical and education infrastructure possibly has a similar meaningful impact on income inequality increases. Meanwhile, health infrastructure development has the least impact on income inequality increases in Indonesia compared to physical and education infrastructure. An increase in health infrastructure might increase income inequality in Indonesia by 0.02 at a $10 \%$ significant level, other factors being equal, according to the estimates in Column [3].

Regarding the impact of physical infrastructure (transportation, telecommunications, electricity), Table 2 reports a positive tendency of physical infrastructure and income inequality relationship. However, the result is not robustly significant since only the models in Column [3] and [4] show a significant effect of physical infrastructure on income inequality. The effect of physical infrastructure on income inequality in Indonesia remains unchanged after considering social infrastructure (education and health). It is in accordance with Makmuri (2017), who claims the tendency of the physical infrastructure to increase income inequality in Indonesia. Makmuri (2017) explains that the positive relationship between physical infrastructure, especially transportation and telecommunications, and income inequality may be caused by uneven returns received by the different income groups. Bricefio-Garmendia and Kyltchnikova (2006, as cited in Cook, 2011) find strong gaps of access to infrastructure between the two income groups in poorer countries.

As argued by Makmuri (2017), different returns received by the poor and the rich may explain the positive physical infrastructure-income inequality relationship in Indonesia. Specifically, he argues that improvement in transportation infrastructure is associated with higher sales of private cars and motorcycles by the middle-up income group, which can provide better access to economic productivity. Meanwhile, telecommunications are argued to be associated with technological bias, which mostly favors high-skilled laborers. Exploring the impact of telecommunications using ICT (information, communication, and technology) adoption ratio confirmed that telecommunications increase provincial income inequality in Indonesia (Patria \& Erumban, 2020). Furthermore, Patria and Erumban (2020) state that the ICT adoption rate also has an inverted-U shape relationship with income inequality in which the income distribution could have better distributed as the ICT adoption rate gets higher. They also argue that the positive ICT adoption rate-income inequality relationship may be caused by the rich adopting and benefiting ICT earlier than the poor. Similarly, electricity in Indonesia may also benefit the middle-up income group more than the low-income group. It is reported that the poor in Indonesia obtain a smaller return from improvement in electricity compared to the rich (Balisacan et al., 2002).

In addition to the unequal returns to infrastructure, the fact that physical infrastructure may foster trade openness and industries that maintain technological progress and require high-skilled laborers probably explains the positive physical infrastructure-income inequality relationship, although it only shows a little evidence. As the economy in Indonesia becomes more open and industry comes to dominate the economy, the demand for high-skilled laborers may also increase. Statistics Indonesia (BPS) reports that compared to other economic sectors, the industry contributes the most (19.86\%) to the total Indonesian national income in 2018. Therefore, it is likely that along with the tendency to be more open to trade and the domination of the modern sector in Indonesia, the impact of physical infrastructure in increasing income inequality is stronger when the skill gaps also remain large.

Similar to physical infrastructure, education infrastructure (primary and high education) seems to be positively associated with income inequality though not robustly significant. In contrast with Majumder (2012) and More and Aye (2017), this study finds that improved access to education infrastructure in Indonesia tends to increase income inequality. Meanwhile, supporting this finding, Chongvilaivan dan Kim (2016) finds that education gaps in Indonesia dominantly lead to income inequality increases. A positive higher education-income inequality relationship is also found in emerging developing countries (Coady \& Dizioli, 2018) and Islamic countries (Shahabadi et al., 2018) like Indonesia. In addition, Wells (2006) mentions numerous studies that support the positive relationship between education and income inequality, including Barro (2000). 
The positive relationship between education infrastructure and income inequality could be explained by unequal access, in particular to higher education, between the two income groups due to financial constraints of the poor (Chongvilaivan \& Kim, 2016; Muttaqin, 2018; Wicaksono et al., 2017) and high educational cost (Shahabadi et al., 2018). Using data in 2007 and a Theil decomposition analysis, Chongvilaivan and Kim (2016) claim that education gaps in Indonesia dominantly lead to income inequality increases. Particularly, increases in higher education infrastructure in urban regions in Indonesia are found to foster education gaps and consequently contribute to increases in national income inequality (Akita, 2017; Akita \& Miyata, 2013; Hayashi et al., 2014). Higher education has been found to contribute to income inequality increases when an economy shifts from agriculture to modern sectors in developing countries (Barro, 2000; Wells, 2006). Barro (2000) finds that the higher level of education attained, the greater income inequality will be. Furthermore, Wells (2006) explains that the role of higher education becomes more significant during the shift because labor demand for high-skilled laborers increases. If only the middle-up income groups can attain higher education, they will become richer while the poor remain poor. The income gap may remain large if there is still a large education gap.

Shahabadi et al. (2018) state that the poor are unlikely to have sufficient financial resources to achieve higher education because of the high educational cost, especially higher education. Family factors like financial resources are believed to be a determinant factor of the unequal access to education in Indonesia (Muttaqin, 2018). The World Inequality Database on Education reports that in 2012, in Indonesia, only $8 \%$ of the poor and $5 \%$ of the poorest aged 18 to 22 years old had attended higher education, and only $1 \%$ of the poorest and $5 \%$ of the poor aged 25 to 29 years old had completed tertiary education. Furthermore, the middle-up income group, especially in urban areas in Indonesia, prefers sending their children to private schools, including international schools, which cost substantially more than public schools. It proves the statement that differences in physical and human capital equipment used in schooling also contribute to unequal access to higher education (Orazem \& King, 2007; Yang \& Qiu, 2016). Private schools, especially at the higher education level, in Indonesia, are found to produce better-performing graduates in the labor market than public schools due to their management structure (Bedi \& Garg, 2000). Private schools seem to have more authority to manage their schools and provide better physical and human capital resources to offer education programs.

Education infrastructure has different impacts in developing and developed regions in Indonesia (Saraswati, 2013). Saraswati (2013) explains that public education investment has less effect on human capital improvement in developed regions, whereas the impact is more significant for developing regions. Majumder (2012) shows that the impact of social infrastructure in India is significant in intermediate regions and insignificant in developed and lagging regions. Furthermore, the returns to education on income inequality in emerging countries are significant in the long-term but insignificant in the short-term (Chani et al., 2014; Checchi \& van de Werfhorst, 2014; Qazi et al., 2018). Therefore, a longer period is probably needed to clearly depict the returns to education investment on income inequality in Indonesia.

As for health infrastructure (doctors, hospitals, water, sanitation), it seems that this study only gives little evidence that health infrastructure has an impact on income inequality. Probably due to the unstable variable of health infrastructure, implied by only one model in Column [1] that shows significant estimates, this study cannot definitely state that the two variables are associated. Despite the little evidence, the positive relationship is in contrast with previous studies, including Majumder (2012) and More and Aye (2017). In Indonesia, the positive relationship is possibly caused by uneven access to health services between the two income groups. There is a positive trend about the gaps of access to clean water and improved sanitation between the poor and the rich in Indonesia (Pitriyan \& Siregar, 2013; World Health Organization, 2017). Moreover, people living in remote areas and remote islands still have difficulties in accessing health services (hospital and primary health service/Puskesmas), safe water, and improved sanitation (Benotti et al., n.d.; Mahendradhata et al., 2017; World Health Organization, 2017).

\section{Conclusions}

This study contributes to the infrastructure-income inequality literature in Indonesia by assessing the impact of social infrastructure (education and health) on income inequality and physical infrastructure. Moreover, this study obtains more infrastructure and modern telecommunications indicators that are more related to the modern economic era. Using 34 unbalanced provincial panel data, between 2009 and 2017, this study constructs infrastructure summary indices and applies a panel data regression analysis, GMM, to estimate the impact of infrastructure on income inequality. 
The main finding of this study is that both physical and social infrastructures, specifically education infrastructure, appear to be positively associated with income inequality increases in Indonesia, although they are not robustly significant. Even after taking social infrastructure into account, physical infrastructure still seems to increase income inequality in Indonesia. Meanwhile, this study cannot definitely draw a conclusion regarding the nexus between health infrastructure and income inequality in Indonesia due to little evidence. The tendency of physical and social (education) infrastructure to increase income inequality is probably caused by uneven returns to infrastructure received between income groups, inadequate access to infrastructure for the poor, and insufficient financial resources of the poor to access higher education.

Taking everything into consideration, the author acknowledges some limitations of this study that need some improvements in further research. First, future studies could improve the data used by providing more balanced panel data with a more extended period applied. Second, future studies may improve this study by considering seaports and airports as indicators for transportation, in addition to land transportation. Third, considering the possibility of different returns to infrastructure development received between income groups, the impact of infrastructure may be various. According to previous empirical studies, the impact of education infrastructure is also different regarding the development level of the region and length of the period. Accordingly, investigating the impact of infrastructure on income inequality between those various different factors as the dependent variables may be advantageous to depict stronger evidence of the heterogeneous impact of infrastructure on income inequality in Indonesia.

In spite of the tendencies of infrastructure to increase income inequality, this study has no intention to neglect the role of infrastructure in improving income distribution. It seems that uneven access to infrastructure may lead to different returns to physical infrastructure between income groups. Particularly, price and financial resources tend to constrain the poor from accessing social infrastructure, especially education infrastructure. Therefore, it is suggested that the government provide more even access to physical infrastructure at an affordable price, especially for the poor, to promote opportunities in economic activities, labor market, and higher income. As for social infrastructure, it will be better if the government provides more equal access to social infrastructure with affordable costs, especially for the poor. Furthermore, improvement of the mechanism and distribution of financial support to the poor is necessary to enable them to achieve higher education, better health conditions, and eventually earn a higher income. By ensuring returns to physical infrastructure are well received by all income groups and narrowing the endowment gaps between different income groups, it is expected that income distribution will improve in Indonesia.

\section{Acknowledgments}

I gratefully appreciate the financial contribution of the National Development Planning Agency of Indonesia through its Professional Human Resource Development Program (PHRD) IV. I would also like to express my gratitude for the technical contribution of the Ministry of Agrarian and Spatial Affairs/National Land Agency. Through those contributions, I can complete my study at Universitas Indonesia and Kobe University.

\section{Reference}

Akita, T. (2017). Educational expansion and the role of education in expenditure inequality in indonesia since the 1997 financial crisis. Social Indicators Research, 130(3), 1165-1186. https://doi.org/10.1007/s11205-015-1208-y

Akita, T., \& Miyata, S. (2013). The roles of location and education in the distribution of economic wellbeing in indonesia: hierarchical and non-hierarchical inequality decomposition analyses. Letters in Spatial and Resource Sciences, 6(3), 137-150. https://doi.org/10.1007/s12076-013-0093-8

Bajar, S., \& Rajeev, M. (2016). The impact of infrastructure provisioning on inequality in india: does the level of development matter? Journal of Comparative Asian Development, 15(1), 122-155. https://doi.org/10.1080/15339114.2016.1150188 
Balisacan, A. M., Pernia, E. M., \& Asra, A. (2002). Revisiting growth and poverty reduction in indonesia: what do subnational data show? Bulletin of Indonesian Economic Studies, 39(3), 329-351. https://doi.org/10.1080/0007491032000142782

Banerjee, S. B., \& Jackson, L. (2017). Microfinance and the business of poverty reduction: critical perspectives from rural Bangladesh. Human Relations, 70(1), 63-91. https://doi.org/10.1177/0018726716640865

Barro, R. J. (2000). Inequality and growth in a panel of countries. Journal of Economic Growth, 5(1), 5-32. https://doi.org/10.1023/A:1009850119329

Bedi, A. S., \& Garg, A. (2000). The effectiveness of private versus public schools: the case of Indonesia. Journal of Development Economics, 61(2), 463-494. https://doi.org/10.1016/S03043878(00)00065-1

Benotti, E., Hirschhorn, L., Sugiyarso, S., \& Ahmad, J. (n.d.). Indonesia: puskesmas and the road to equity and access. Primary Health Care Performance Initiative. Retrieved June 12, 2020, fromhttps://improvingphc.org/indonesia-puskesmas-and-road-equity-and-access

Biller, D., Andrés, L., \& Dappe, M. H. (2014). Infrastructure gap in South Asia : inequality of access to infrastructure services. The World Bank. https://doi.org/10.1596/1813-9450-7033

Bouillon, C. P., Legovini, A., \& Lustig, N. (2003). Rising inequality in Mexico: household characteristics and regional effects. The Journal of Development Studies, 39(4), 112-133. https://doi.org/10.1080/713869428

Calderón, C., Moral-Benito, E., \& Servén, L. (2014). Is infrastructure capital productive? A dynamic heterogenous approach. Journal of Applied Econometrics, 30(2), 177-198. https://doi.org/10.1002/jae.2373

Calderón, C., \& Servén, L. (2004, September 1). The effects of infrastructure development on growth and income distribution. World Bank Group. http://documents.worldbank.org/curated/en/438751468753289185/The-effects-ofinfrastructure-development-on-growth-and-income-distribution

Chani, M. I., Jan, S. A., Pervaiz, Z., \& Chaudhary, A. R. (2014). Human capital inequality and income inequality: testing for causality. Quality and Quantity, 48(1), 149-156. https://doi.org/10.1007/s11135-012-9755-7

Charlery, L. C., Qaim, M., \& Smith-Hall, C. (2016). Impact of infrastructure on rural household income and inequality in Nepal. Journal of Development Effectiveness, 8(2), 266-286. https://doi.org/10.1080/19439342.2015.1079794

Checchi, D., \& van de Werfhorst, H. G. (2014). Educational policies and income inequality. IZA Discussion Paper, (8222). http://ftp.iza.org/dp8222.pdf

Chong, A., \& Calderón, C. (2004). Volume and quality of infrastructure and the distribution of income: an empirical investigation. Review of Income and Wealth, 50(1), 87-106. https://doi.org/10.1111/j.0034-6586.2004.00113.x

Chongvilaivan, A., \& Kim, J. (2016). Individual income inequality and its drivers in indonesia: a theil decomposition reassessment. Social Indicators Research, 126(1), 79-98. https://doi.org/10.1007/s11205-015-0890-0

Coady, D., \& Dizioli, A. (2018). Income inequality and education revisited: persistence, endogeneity and heterogeneity. Applied Economics, 50(25), 2747-2761.. https://doi.org/10.1080/00036846.2017.1406659

Cook, P. (2011). Infrastructure, rural electrification and development. Energy for Sustainable Development, 15(3), 304-313. https://doi.org/10.1016/j.esd.2011.07.008

De, P. K., \& Halder, I. I. (2016). Inequality in asia: convergence and determinants. ARTNeT Working Paper Series (158). https://www.unescap.org/sites/default/d8files/knowledgeproducts/AWP\%20No.\%20158F.pdf

Doumbia, D., \& Kinda, T. (2019). Reallocating public spending to reduce income inequality : can it work?. International Monetory Fund (WP/19/188). https://www.imf.org/en/Publications/WP/Issues/2019/09/06/Reallocating-Public-Spending-toReduce-Income-Inequality-Can-It-Work-48607

Hasanov, F., \& Izraeli, O. (2011). Income inequality, economic growth, and the distribution of income gains: Evidence from the U.S. States. Journal of Regional Science, 51(3), 518-539. https://doi.org/10.1111/j.1467-9787.2010.00700.x

Hayashi, M., Kataoka, M., \& Akita, T. (2014). Expenditure inequality in indonesia, 2008-2010: a spatial decomposition analysis and the role of education. Asian Economic Journal, 28(4), 389-411. 
https://doi.org/10.1111/asej.12042

Hill, H., Resosudarmo, B. P., \& Vidyattama, Y. (2008). Indonesia's changing economic geography. Bulletin of Indonesia Economic Studies, 44(3), 407-435. https://doi.org/10.1080/00074910802395344

Hooper, E., Peters, S., \& Pintus, P. (2018). To what extent can long-term investments in infrastructure reduce inequality? Journal of Infrastructure, Policy and Development, 2(2), 193-225. https://doi.org/10.24294/jipd.v2i2.858

Jones, R., \& Llewellyn, J. (2019). Improving infrastructure. National Institute Economic Review, 250(1), R61-R68. https://doi.org/10.1177/002795011925000119

Kai, H., \& Hamori, S. (2009). Microfinance and Inequality. Research in Applied Economics, 1(1), 1-12. https://doi.org/10.5296/rae.v1i1.304

Kannan, R., Morris, N., Sibarani, L. A., \& Handari, A. (2018). The Impact of Indonesia's Infrastructure Delivery. Tusk Advisory. http://tuskadvisory.com/Document/The\%20Impact\%20of\%20Indonesia's\%20Infrastructure\%20De livery.pdf

Li, B., Li, T., Yu, M., \& Chen, B. (2017). Can equalization of public services narrow the regional disparities in China? A spatial econometrics approach. China Economic Review, 44, 67-78. https://doi.org/10.1016/j.chieco.2017.03.010

Mahendradhata, Y., Trisnantoro, L., Listyadewi, S., Soewondo, P., MArthias, T., Harimurti, P., \& Prawira, J. (2017). The republic of indonesia health system review, health systems in transition, vol-7 no.1. World Health Organization. https://apps.who.int/iris/handle/10665/254716

Majumder, R. (2012). Removing poverty and inequality in India: the role of infrastructure. MPRA Paper (40941). https://mpra.ub.uni-muenchen.de/40941/

Makmuri, A. (2017). Infrastructure and inequality: An empirical evidence from Indonesia. Economic Journal of Emerging Markets, 9(1), 29-39. https://doi.org/10.20885/ejem.vol9.iss1.art4

More, I., \& Aye, G. C. (2017). Effect of social infrastructure investment on economic growth and inequality in South Africa: A SEM approach. International Journal of Economics and Business Research, 13(2), 95-109. https://doi.org/10.1504/IJEBR.2017.082268

Muttaqin, T. (2018). Determinants of unequal access to and quality of education in Indonesia. Jurnal Perencanaan Pembangunan: The Indonesian Journal of Development Planning, 2(1), 1-23. https://doi.org/10.36574/jpp.v2i1.27

Orazem, P. F., \& King, E. M. (2007). Schooling in developing countries: the roles of supply, demand and government policy. Handbook of Development Economics, 4, 3475-3559. https://doi.org/10.1016/S1573-4471(07)04055-7

Patria, H., \& Erumban, A. (2020). Impact of ict adoption on inequality. The Journal of Indonesia Sustainable Development Planning, 1(2), 125-139. https://doi.org/10.46456/jisdep.v1i2.58

Pitriyan, P., \& Siregar, A. Y. (2013). Health inequity in indonesia : is it declining? Working Paper in Economics and Development Studies, (201316). Bandung: Department of Economics Padjajaran University. http://ceds.feb.unpad.ac.id/wopeds/201316.pdf

Qazi, W., Raza, S. A., Jawaid, S. T., \& Karim, M. Z. A. (2018). Does expanding higher education reduce income inequality in emerging economy? Evidence from Pakistan. Studies in Higher Education, 43(2), 338-358. https://doi.org/10.1080/03075079.2016.1172305

Raychaudhuri, A., \& De, P. (2010). Trade, infrastructure and income inequality in selected asian countries: An empirical analysis. Asia-Pacific Research and Training Network on Trade Working Paper Series, (82). https://www.unescap.org/sites/default/files/AWP No. 82.pdf

Röller, L., \& Waverman, L. (2001). Telecommunications infrastructure and economic development: a simultaneous approach. The American Economic Review, 91(4), 909-923. https://www.jstor.org/stable/2677818?seq=1\#metadata_info_tab_contents

Roodman, D. (2009). Practitioners' corner: A note on the theme of too many instruments. Oxford Bulletin of Economics and Statistics, 71(1), 135-158. https://doi.org/10.1111/j.1468-0084.2008.00542.x

Saraswati, E. (2013). Public spending education and inequality: a case study in indonesia. International Journal of Social Science and Humanity, 2(5), 427-431. https://doi.org/10.7763/ijssh.2012.v2.139

Seneviratne, D., \& Sun, Y. (2013). Infrastructure and income distribution in asean-5: what are the links? IMF Working Papers, 13(41). https://doi.org/10.5089/9781589068018.001

Shahabadi, A., Nemati, M., \& Hosseinidoust, S. E. (2018). The effect of education on income inequality in selected Islamic countries. International Journal of Asia-Pacific Studies, 14(2), 61-78. https://doi.org/10.21315/ijaps2018.14.2.3 
Straub, S., \& Fay, M. (2019). Rising incomes and inequality of access to infrastructure among latin american households. Journal of Infrastructure, Policy and Development, 3(1), 76-99. https://doi.org/10.24294/jipd.v3i1.1086

Telecommunications Statistics of Indonesia. Jakarta: Statistics Indonesia (BPS)

Tian, G., \& Li, J. (2019). How does infrastructure construction affect economic development along the "belt and road": by promoting growth or improving distribution? Emerging Markets Finance and Trade, 55(14), 3332-3348. https://doi.org/10.1080/1540496X.2019.1607725

Torrisi, G. (2009, January 25). Public Infrastructure: definition, classification and measurement issues. MPRA Paper, (12990). https://mpra.ub.uni-muenchen.de/12990/

United Nations. (2016). Global sustainable 2016 edition global sustainable. https://sustainabledevelopment.un.org/index.php?page=view\&type=400\&nr=2328\&menu=1515

Mendoza, O. M. V. (2017). Infrastructure development, income inequality and urban sustainability in the People's Republic of China. ADBI Working Paper, (713). Tokyo: Asian Development Bank Institute. https://www.adb.org/publications/infrastructure-development-income-inequality-and-urbansustainability-prc

Wells, R. (2006). Education's effect on income inequality: an economic globalisation perspective. Globalisation, Societies and Education, 47(3), 391-391. https://doi.org/10.1080/14767720600955428

Wicaksono, E., Amir, H., \& Nugroho, A. (2017). The Source of Income Inequality in Indonesia: A RegressionBased Inequality Decomposition. ADBI Working Paper, (667). Tokyo: Asian Development Bank Institute. https://www.adb.org/publications/sources-income-inequality-indonesia

World Bank. (2016). Indonesia's Rising Divide. Washington DC: The World Bank. http://pubdocs.worldbank.org/en/16261460705088179/Indonesias-Rising-Divide-English.pdf

World Health Organization. (2017). State of health inequality: Indonesia. Geneva: World Health Organization. https://www.who.int/gho/health_equity/report_2017_indonesia/en/

Yang, J., \& Qiu, M. (2016). The impact of education on income inequality and intergenerational mobility. China Economic Review, 37, 110-125. https://doi.org/10.1016/j.chieco.2015.12.009

Zhang, R., \& Ben Naceur, S. (2019). Financial development, inequality, and poverty: Some international evidence. International Review of Economics and Finance, 61, 1-16. https://doi.org/10.1016/j.iref.2018.12.015

Zhuang, J., Kanbur, R., \& Rhee, C. (Eds.). (2014). Inequality in asia and the pacific: trends, drivers, and policy implications. Co-Publication of the Asian Development Bank and Routledge. . http://hdl.handle.net/11540/4723 